\title{
DISTRIBUTION OF SOCIAL WASPS IN VIETNAM (HYMENOPTERA: VESPIDAE)
}

\author{
Nguyen Thi Phuong Lien ${ }^{1 *}$, Junichi Kojima² \\ ${ }^{1}$ Institute of Ecology and Biological Resources, VAST, *phuonglientit@yahoo.com \\ ${ }^{2}$ Natural History Laboratory, Faculty of Science, Ibaraki University, Mito, 310-8512 Japan
}

\begin{abstract}
Distribution records of social wasps in Vietnam are summarized and their distribution patterns are discussed. A total of 76 species in 11 genera of social wasps are recognized in Vietnam. They are 11 species belonging to four genera of the subfamily Stenogastrinae, 51 species in four genera of the Polistinae and 14 species belonging to three genera of the Vespinae. Distribution records of social wasps in Vietnam are given according to the three climatic conditions (Northern, Southern and Mountainous areas), showing that the numbers of species are higher in the mountainous areas and tend to decrease from north to south. Vietnam has a rich social wasp fauna, consisting of three major components: the northern element, of which the center of divergence might be on the eastern slope of Himalaya; the Sundaland species, which are distributed in the southern part of Vietnam; and species widely distributed in the IndoMalayan region.
\end{abstract}

Keywords: Vespidae, climatic condition, distribution, social wasps, fauna, Vietnam.

\section{INTRODUCTION}

Social wasps, namely Stenogastrinae (hover wasps), Polistinae (paper wasps) and Vespinae (hornets and yellow-jackets) in the family Vespidae, consisting of about 1,000 described species worldwide, are beneficial insects in that they may attack many agricultural pests to feed their young [8, 11, 32], and thus they are, at least potentially, effective predators of insect pests in biological control programs [15, 10]. Also, because they are at the top-position in a food-web of terrestrial arthropods as well as pollinators of many plants [18, 7, 17], social wasps play important roles in an ecosystem where they occur, and thus they can be good bio-indicators for environmental conditions. Besides these subjects considered in relation to human life, the social wasps have provided us with enormous opportunities to study the origin and process of evolution of eusociality in hymenopterans and insects in general $[16,14,1]$.

Vietnam's land is long and narrow, spreading from 8.5 to 23 degree north latitude and with the coastline of about $3,000 \mathrm{~km}$ long. As its geographical consequence Vietnam has a peninsula feature: The effect of the sea spreads over the area except in the northwestern part, where it has more or less continental inland climate [22]. Furthermore, although Vietnam is located south of the Tropics of Cancer, its climate is not simply tropical but varies largely according to regions possibly because of presence of several mountain chains. All such geographical and climatic features of Vietnam allow us to expect that Vietnam harbors a rich biota. The social wasps should not be exceptional. Neverthelss taxonomic and faunal researches on Vietnamese social wasps had only recently been commenced by the first author with her colleagues [23-27, 30-32]. Through these works, a total of 49 species of social wasps have been recognized in Vietnam as summarized in this paper.

\section{MATERIALS AND METHODS}

The present study was based on the data given in several publications [23-33], specimens collected from 2000 to 2007 through out Vietnam, and those collected through the field trips to the northern parts and Tay Nguyen plateau of Vietnam from 2008 to 2013.

\section{RESULTS AND DISCCUSSION}

Subfamily Stenogastrinae

In the Stenogastrinae, 61 species in seven genera (five South Asian, two Papuan) have been recognized [5, 6, 33, 34]. In Vietnam, 11 species belonging to four South Asian genera are recognized [25, 30, 33, 35] (table 2). 
Subfamily Polistinae

Polistinae, with about 980 extant species in 25 genera [3, 12, 13], are grouped into four monotypic tribes; the cosmopolitan tribe Polistini (=Polistes), the New World endemic Mischocyttarini (=Mischocyttarus) and Epiponini (19 genera), and the Old World endemic Ropalidiini (four genera). The genus
Polistes is divided into four subgenera [2]: the New World subgenus Aphanilopterus; Polistes s. str., primarily Palaearctic and African, with a few species penetrating into the Oriental region; Gyrostoma, widely distributed in Asia, Pacific islands including New Guinea and Australia; and Polistella, occurring widely in the Old World other than Europe and Africa north of the Sahara.

Table 1. Natural occurrence of the Oriental social wasp genera in Vietnam and other zoogeographical regions

\begin{tabular}{|l|c|c|c|c|c|c|}
\hline \multicolumn{1}{|c|}{ Genus } & Vietnam & Australian & Palaearctic & Ethiopian & Nearctic & Neotropical \\
\hline $\begin{array}{l}\text { Cochlischnogaster } \\
\text { Dong and Otsuka }\end{array}$ & + & - & - & - & - & - \\
\hline $\begin{array}{l}\text { Eustenogaster van der } \\
\text { Vecht }\end{array}$ & + & - & - & - & - & - \\
\hline $\begin{array}{l}\text { Liostenogaster van } \\
\text { der Vecht }\end{array}$ & + & - & - & - & - & - \\
\hline $\begin{array}{l}\text { Metischnogaster van } \\
\text { der Vecht }\end{array}$ & - & - & - & - & - & - \\
\hline $\begin{array}{l}\text { Parischnogaster von } \\
\text { Schulthess }\end{array}$ & + & - & - & - & - & - \\
\hline Polistes Latreille & + & + & + & + & + & + \\
\hline $\begin{array}{l}\text { Belonogaster de } \\
\text { Saussure }\end{array}$ & - & - & - & + & - & - \\
\hline Ropalidia (de Saussure) & + & + & - & + & - & - \\
\hline $\begin{array}{l}\text { Parapolybia de } \\
\text { Saussure }\end{array}$ & + & + & + & - & - & - \\
\hline Polybioides du Buysson & + & - & - & + & - & - \\
\hline $\begin{array}{l}\text { Dolichovespula } \\
\text { Rohwer }\end{array}$ & - & - & + & - & + & - \\
\hline Provespa Ashmead & + & - & - & - & - & - \\
\hline Vespa Linnaeus & + & + & + & + & - & - \\
\hline Vespula Thomson & + & - & + & - & + & - \\
\hline
\end{tabular}

In Ropalidiini, Belonogaster is predominantly African, with four species occurring in Arabian Peninsula and one in India [9]: in Parapolybia, six species are currently recognized, two in the Middle East, and four in the Oriental region; Polybioides show a disjunct distribution pattern, with two continental African species and four species distributed in Southeast Asia; Ropalidia, the largest genus in the tribe in term of the number of species, [1921], is distributed in most of tropical and subtropical areas of the Old World. In Vietnam,
51 species in four Polistinae genera have so far been recorded [28, 29, this study]: 27 Polistes (5 Gyrostoma and 22 Polistella); 24 Ropalidinii species (20 Ropalidia, 3 Parapolybia, and 1 Polybioides) (table 2).

\section{Subfamily Vespinae}

Vespinae includes four extant genera (Dolichovespula, Provespa, Vespa and Vespula); all are found in Asia and the nocturnal genus, Provespa, is endemic to eastern Asian tropics [4]. 
In Vietnam, 14 species belonging to three genera (Provespa, Vespa and Vespula) are recognized [23] (table 2).
In total, 76 species of social wasps have been recorded in Vietnam as show in table 2 .

Table 2. Climatic distribution of the Vietnamese social wasps

\begin{tabular}{|c|c|c|c|c|}
\hline \multirow{2}{*}{ Taxon } & \multicolumn{3}{|c|}{ Climatic area } & \multirow{2}{*}{$\begin{array}{c}\text { Zoogeogr- } \\
\text { aphical } \\
\text { Region }\end{array}$} \\
\hline & $\mathrm{N}$ & M & $\mathrm{S}$ & \\
\hline \multicolumn{5}{|l|}{ Subfamily Stenogastrinae } \\
\hline 1. Cochlischnogaster daduganensis Dong and Otsuka & - & + & - & $\mathrm{O}$ \\
\hline 2. Cochlischnogaster spatulata (Carpenter and Starr) & + & + & - & $\mathrm{O}$ \\
\hline 3. Cochlischnogaster sp. & - & + & - & $\mathrm{O}$ \\
\hline 4. Eustenogaster nigra Saito and Nguyen & + & + & - & $\mathrm{O}$ \\
\hline 5. Eustenogaster scitula (Bingham) & + & + & + & $\mathrm{O}$ \\
\hline 6. Eustenogaster vietnamensis Saito & - & + & - & $\mathrm{O}$ \\
\hline 7. Liostenogaster filicis Turillazzi & + & + & + & $\mathrm{O}$ \\
\hline 8. Liostenogaster nitidipennis (de Saussure) & - & - & + & $\mathrm{O}$ \\
\hline 9. Parischnogaster mellyi (de Saussure) & + & + & + & $\mathrm{O}$ \\
\hline 10. Parischnogaster striatula (du Buysson) & - & - & + & $\mathrm{O}$ \\
\hline 11. Parischnogaster sp. & + & - & - & $\mathrm{O}$ \\
\hline \multicolumn{5}{|l|}{ Subfamily Polistinae } \\
\hline 12. Polistes gigas (Kirby) & + & + & + & $\mathrm{O}$ \\
\hline 13. Polistes olivaceus (DeGeer) & + & - & + & $\mathrm{O}$ \\
\hline 14. Polistes rothneyi Cameron & + & + & - & $\mathrm{O}, \mathrm{P}$ \\
\hline 15. Polistes tenebricosus Lepeletier & + & + & + & $\mathrm{O}$ \\
\hline 16. Polistes sp. A & - & - & + & $\mathrm{O}$ \\
\hline 17. Polistes affinis Gusenleitner & - & + & - & $\mathrm{O}$ \\
\hline 18. Polistes brunetus Nguyen \& Kojima & + & + & - & $\mathrm{O}$ \\
\hline 19. Polistes clandestinus Nguyen, Kojima \& Saito & - & + & - & $\mathrm{O}$ \\
\hline 20. Polistes curcipunctum Nguyen, Kojima \& Saito & - & + & - & $\mathrm{O}$ \\
\hline 21. Polistes dawnae Dover and Rao & - & + & - & $\mathrm{O}$ \\
\hline 22. Polistes delhiensis Das and Gupta & + & - & - & $\mathrm{O}$ \\
\hline 23. Polistes horrendus Gusenleitner & - & + & - & $\mathrm{O}$ \\
\hline 24. Polistes japonicus de Saussure & + & + & + & $\mathrm{O}, \mathrm{P}$ \\
\hline 25. Polistes gilvus Nguyen, Kojima \& Saito & - & + & - & $\mathrm{O}$ \\
\hline 26. Polistes khasianus Cameron & - & + & - & $\mathrm{O}$ \\
\hline 27. Polistes lepcha Cameron & - & + & - & $\mathrm{O}$ \\
\hline 28. Polistes mandarinus de Saussure & - & + & - & $\mathrm{O}, \mathrm{P}$ \\
\hline 29. Polistes nigerrimus Gusenleitner & - & + & - & $\mathrm{O}$ \\
\hline 30. Polistes nigritarsis Cameron & - & + & - & $\mathrm{O}$ \\
\hline 31. Polistes nipponensis Pérez & + & + & - & $\mathrm{O}, \mathrm{P}$ \\
\hline 32. Polistes paco Nguyen, Kojima \& Saito & - & + & - & $\mathrm{O}$ \\
\hline 33. Polistes reliciniclypeus Nguyen, Kojima \& Saito & - & + & - & $\mathrm{O}$ \\
\hline 34. Polistes sagittarius de Saussure & + & + & + & $\mathrm{O}$ \\
\hline 35. Polistes stigma (Fabricius) & - & - & + & $\mathrm{O}, \mathrm{A}$ \\
\hline 36. Polistes strigosus Bequaert & + & + & - & $\mathrm{O}$ \\
\hline
\end{tabular}




\begin{tabular}{|c|c|c|c|c|}
\hline 37. Polistes santoshae Das and Gupta & + & - & - & $\mathrm{O}$ \\
\hline 38. Polistes sp. B & + & + & - & $\mathrm{O}$ \\
\hline 39. Ropalidia artifex (de Saussure) & + & + & + & $\mathrm{O}$ \\
\hline 40. Ropalidia bicolorata van der Vecht & + & + & + & $\mathrm{O}$ \\
\hline 41. Ropalidia birmanica van der Vecht & - & + & - & $\mathrm{O}$ \\
\hline 42. Ropalidia cyathiformis (Fabricius) & + & + & - & $\mathrm{O}$ \\
\hline 43. Ropalidia fasciata (Fabricius) & + & + & + & $\mathrm{O}$ \\
\hline 44. Ropalidia flavopicta (Smith) & + & - & + & $\mathrm{O}$ \\
\hline 45. Ropalidia hongkongensis (de Saussure) & + & + & - & $\mathrm{O}$ \\
\hline 46. Ropalidia magnanima van der Vecht & - & - & + & $\mathrm{O}$ \\
\hline 47. Ropalidia malayana Cameron & - & + & - & $\mathrm{O}$ \\
\hline 48. Ropalidia marginata (Lepeletier) & + & - & + & $\mathrm{O}, \mathrm{A}$ \\
\hline 49. Ropalidia mathematica (Smith) & + & - & - & $\mathrm{O}$ \\
\hline 50. Ropalidia modesta (Smith) & - & - & + & $\mathrm{O}$ \\
\hline 51. Ropalidia nigrita Das and Gupta & - & + & - & $\mathrm{O}$ \\
\hline 52. Ropalidia ornaticeps (Cameron) & + & + & + & $\mathrm{O}$ \\
\hline 53. Ropalidia rufocollaris (Cameron) & + & - & - & $\mathrm{O}$ \\
\hline 54. Ropalidia rufoplagiata (Cameron) & + & - & - & $\mathrm{O}$ \\
\hline 55. Ropalidia stigma (Smith) & + & + & + & $\mathrm{O}$ \\
\hline 56. Ropalidia taiwana Sonan & - & + & - & $\mathrm{O}$ \\
\hline 57. Ropalidia thailandia Gusenleitner & - & + & - & $\mathrm{O}$ \\
\hline 58. Ropalidia vietnama Gusenleitner & - & - & + & $\mathrm{O}$ \\
\hline 59. Parapolybia indica (de Saussure) & + & + & - & $\mathrm{O}, \mathrm{P}$ \\
\hline 60. Parapolybia nodosa van der Vecht & - & + & - & $\mathrm{O}$ \\
\hline 61. Parapolybia varia (Fabricius) & + & + & + & $\mathrm{O}, \mathrm{A}, \mathrm{P}$ \\
\hline 62. Polybioides gracilis van der Vecht & - & - & + & $\mathrm{O}$ \\
\hline \multicolumn{5}{|l|}{ Subfamily Vespinae } \\
\hline 63. Provespa barthelemyi (du Buysson) & + & + & - & $\mathrm{O}$ \\
\hline 64. Provespa nocturna van der Vecht & + & - & + & $\mathrm{O}$ \\
\hline 65. Vespa affinis (Linnaeus) & + & + & + & $\mathrm{O}, \mathrm{A}$ \\
\hline 66. Vespa analis Fabricius & + & + & + & $\mathrm{O}, \mathrm{P}$ \\
\hline 67. Vespa basalis Smith & + & + & + & $\mathrm{O}$ \\
\hline 68. Vespa bicolor Fabricius & + & + & + & $\mathrm{O}$ \\
\hline 69. Vespa ducalis Smith & + & + & - & $\mathrm{O}, \mathrm{P}$ \\
\hline 70. Vespa mandarinia Smith & + & + & - & $\mathrm{O}, \mathrm{P}$ \\
\hline 71. Vespa mocsaryana du Buysson & + & + & + & $\mathrm{O}, \mathrm{P}$ \\
\hline 72. Vespa soror du Buysson & + & + & + & $\mathrm{O}$ \\
\hline 73. Vespa tropica (Linnaeus) & + & + & + & $\mathrm{O}$ \\
\hline 74. Vespa velutina Lepeletier & + & + & + & $\mathrm{O}$ \\
\hline 75. Vespula koreensis (Radoszkowski) & + & + & - & $\mathrm{O}, \mathrm{P}$ \\
\hline 76. Vespula orbata (du Buysson) & + & + & - & $\mathrm{O}$ \\
\hline
\end{tabular}

(+). Present; (-). Absent; O: Oriental; P: Palaearctic; A: Australian.

Distribution pattern of Vietnamese social wasps

Zoogeographical distribution of Vietnamese social wasps
Of the 14 genera so far recorded from the Oriental region, 11 occur in Vietnam (table 1). Among these 11 genera, Polistes occurrs in all the zoogeographical regions, three 
(Parapolybia, Vespa and Vespula) also occur in the Palaearctic Region, three (Ropalidia, Polybioides and Vespa) in the Ethiopian Region, two (Ropalidia and Vespa) in the Australian Region, and Vespula in the Nearctic Region.

In the 11 genera occurring in Vietnam, 76 species (including four undescribed) have been recognized. Of the 72 described species, 25 are restricted to Southeast Asia (17 recorded only in the continent), eleven and four occur also respectively in the Palaearctic and Australian region, and Parapolybia varia is widely distributed in the Oriental, Palaearctic regions and New Guinea (table 2).

Distribution pattern of Vietnamese social wasps in term of climate and altitude

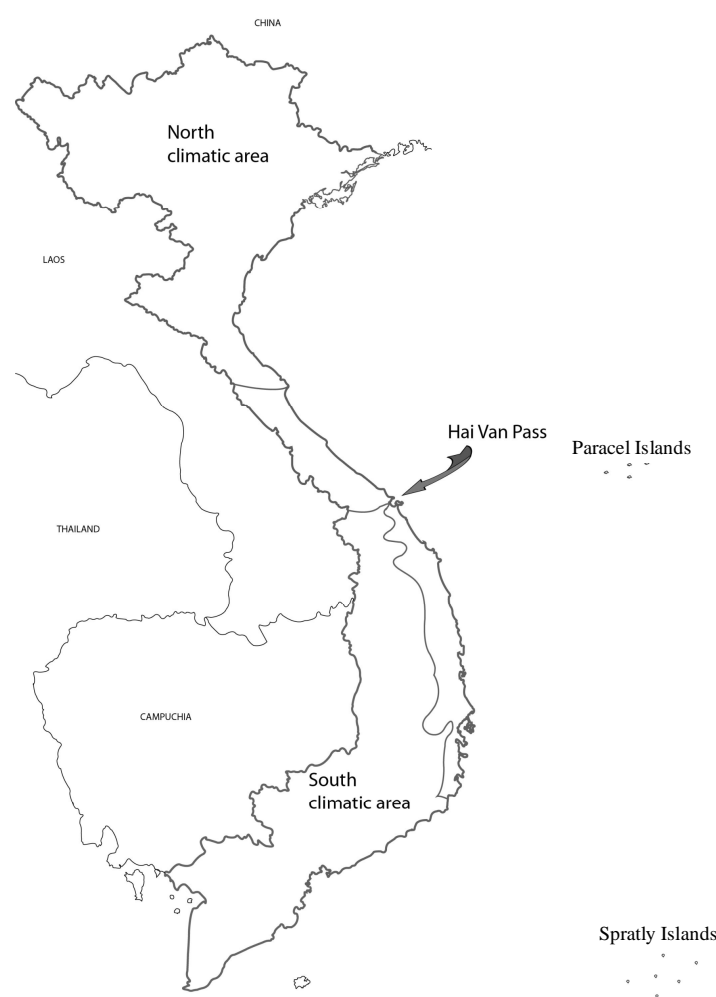

Fig. 1. Map showing climatic areas in Vietnam

Vietnam is often divided into the following three climatic zones: "North Climate" characterized by the monsoon climate with a cool or even cold season is the northern part of Vietnam to Ngang Pass in the south; "South
Climate", monsoon climate without distinct seasonality in temperature, is the southern part of Vietnam from western part of Truong Son, extending southward to eastern part of Nam Bo and Mekong Delta; and "East Truong Son Climate" is the transitional zone between the North and South Climate [22]. On the other hand, the climatic zones in Vietnam in relation to distribution patterns of insects could be categorized in a different way. They could be the Northern area $(\mathrm{N})$ and the Southern area $(\mathrm{S})$, bordered by the Hai Van Mountains (fig. 1); the Northern area has a more or less defined winter, while in the Southern area it is warm or hot throughout the year. Another climatic zone could be a Mountainous area (M), namely areas above $500 \mathrm{~m}$ altitude in the northern part and $700 \mathrm{~m}$ altitude in the southern part. These areas have a cool or even cold season.

Of the 76 social wasp species in 11 genera so far known in Vietnam, the highest number of species (58 species in ten genera) has been recorded in the Mountainous area; 46 species in ten genera were recorded in the Northern area; and the Southern area had the lowest number of social wasps recorded, 33 species in nine genera.

A total of 21 species in seven genera (Eustenogaster, Liostenogaster, Parischnogaster, Polistes, Ropalidia, Parapolybia and Vespa) have been recorded in all the three climatic areas. Six species belonging to three genera (Parischnogaster, Polistes and Ropalidia) have been recorded only in the Northern area, 22 species belonging to four genera (Cochlischnogaster, Eustenogaster, Polistes and Ropalidia) only in the Mountainous area, and seven species belonging to three genera (Eustenogaster, Polistes and Ropalidia) only in the Southern area. The species known only in the Southern area (table 2) are those so far recorded in the southern parts of Southeast Asia or are widely distributed in equatorial or subequatorial areas.

In the Northern area, the highest number of species recorded is in the subfamily Polistinae (27 species in three genera), and 14 species of three genera in the Vespinae and six species in four genera in the Stenogastrinae. 


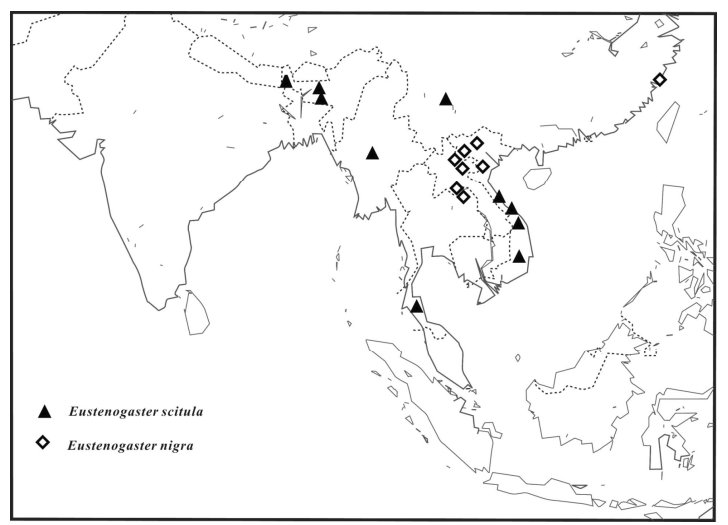

Fig. 2. Map showing the known distribution records of Eustenogaster species

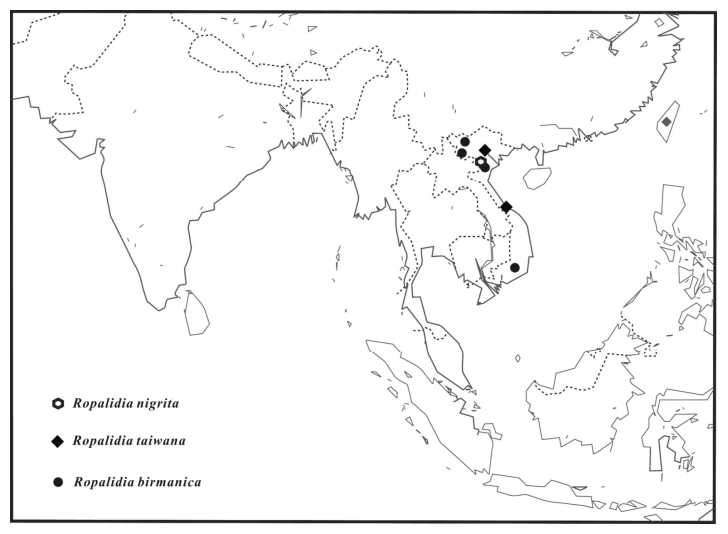

Fig. 4. Map showing the known distribution records of three species of the Ropalidia stigma group

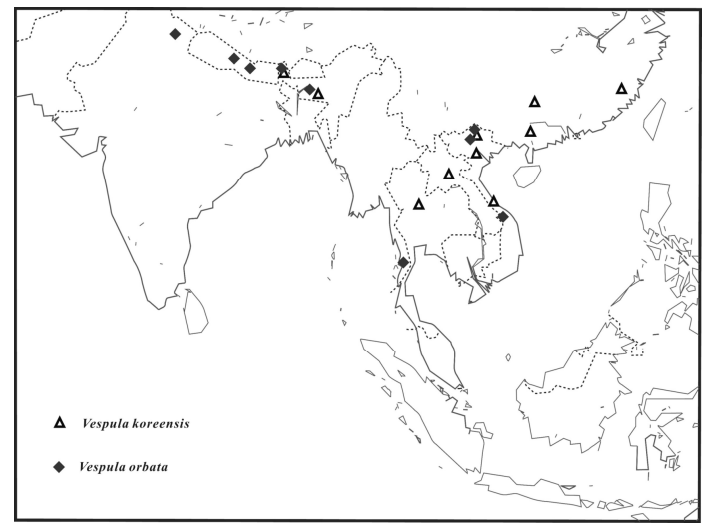

Fig. 6. Map showing the known distribution records of two Vespula species

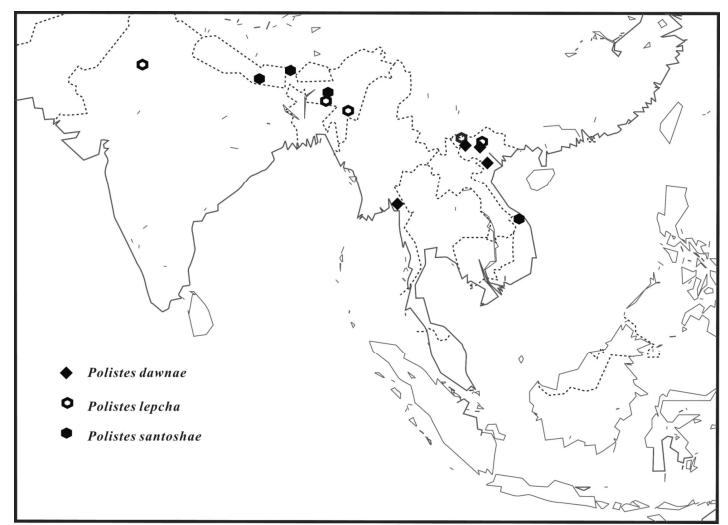

Fig. 3. Map showing the known distribution records of some Polistes species

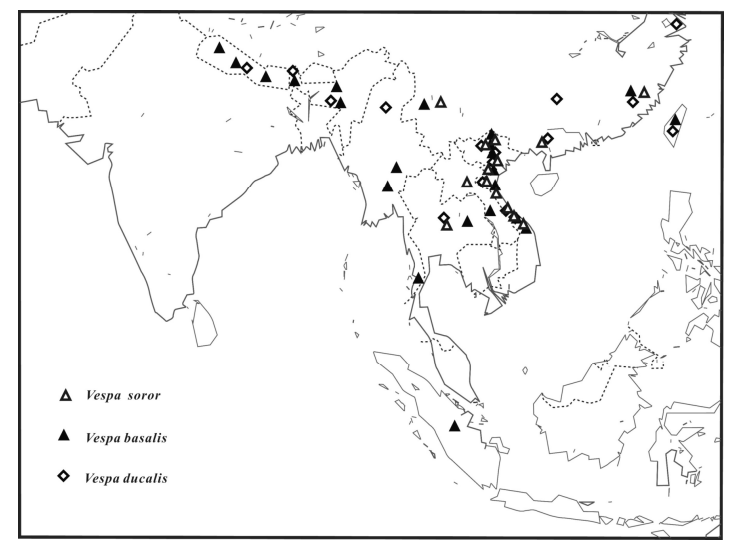

Fig. 5. Map showing the known distribution records of three Vespa species

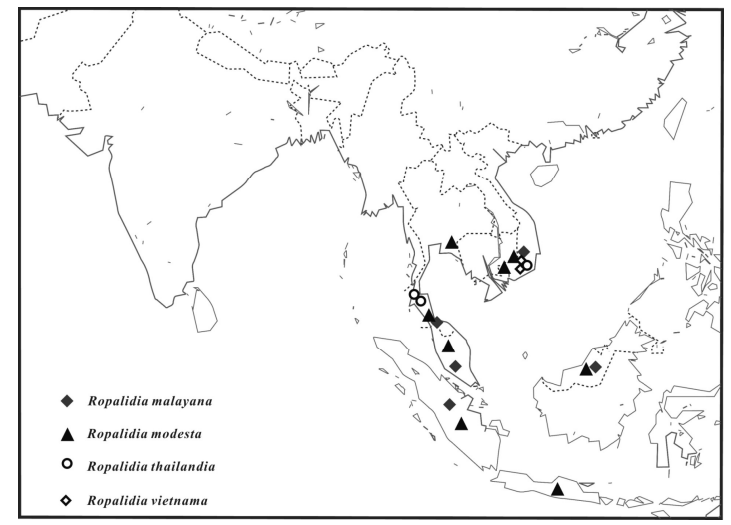

Fig. 7. Map showing the known distribution records of four Ropalidia species occurring in Vietnam 


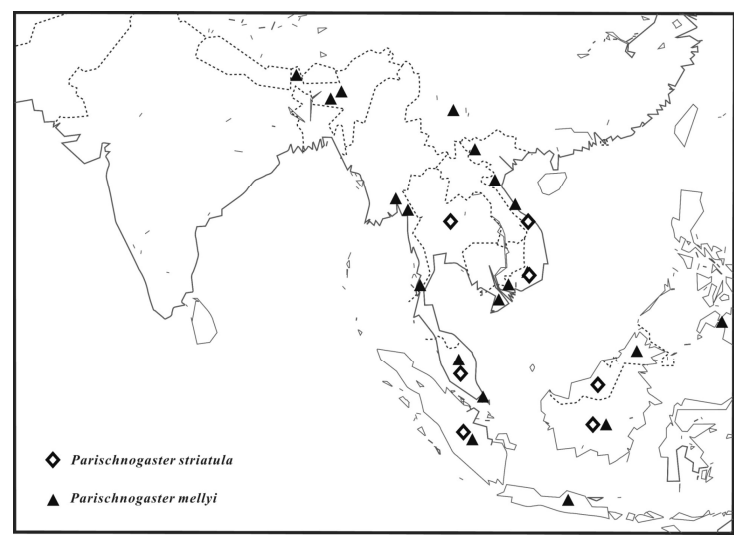

Fig. 8. Map showing the known distribution records of Parischnogaster species

In the Southern area, the Polistinae had the highest number of recorded species (18 species in four genera); 9 species in two genera (Provespa and Vespa) in the Vespinae, and 6 species in three genera in the Stenogastrinae.

\section{Discussion}

Although detailed species-level phylogenetic analyses and historical geography in Southeast Asia are necessary to have a robust scenario for the formation of the present-day social wasp fauna in Vietnam, the Vietnamese social wasp fauna may be considered to include the following three components with respect to their current distribution patterns and their relationships expected from morphological similarities. The first is comprised of northern and/or mountainous species, of which the center of divergence might be in the eastern slope of Himalaya including the northern part of Vietnam. The second includes species which may be the Sundaland origin or which may have originated from Sundaland species. The third consists of the species that are or of which closely related species are widely distributed in South Asia or even to Papuan region.

The species included in the first component would be Cochlischnogaster species, Eustenogaster scitula and E. nigra (fig. 2) in the Stenogastrinae, Polistes species with a basally strongly swollen second metasomal sternum such as $P$. affinis, P. dawnae, P. lepcha (fig. 3),

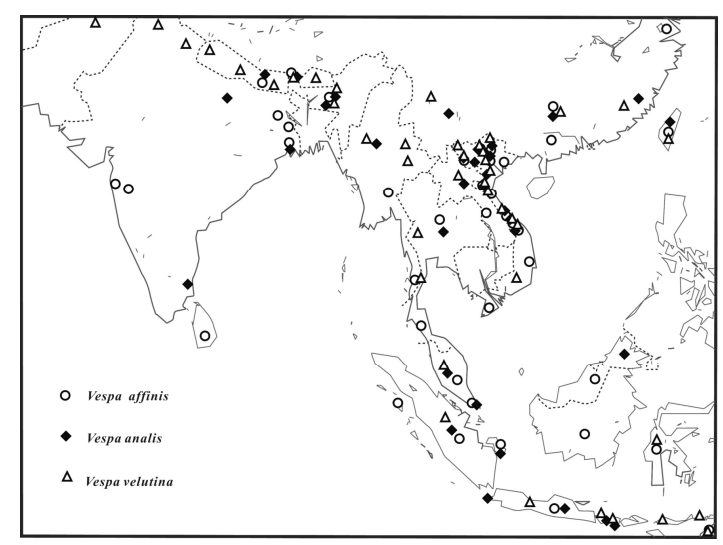

Fig. 9. Map showing the known distribution records of three Vespa species with wide distribution ranges

$P$. mandarinus, and $P$. nigerrimus (see Nguyen et al., 2011), Ropalidia birmanica, R. taiwana, $R$. nigrita (fig. 4), $R$. rufocollaris, and Parapolybia species in the Polistinae, Vespa basalis, V. ducalis, V. soror (fig. 5) and Vespula species (fig. 6) in the Vespinae.

The second component could include Ropalidia malayana, $R$. modesta, $R$. vietnama and $R$. thailandia (fig. 7) in the Polistinae.

The species included in the third component could be Parischnogaster species (fig. 8) in the Stenogastrinae, Polistes (Gyrostoma) species (except Polistes gigas) and Polistes (Polistella) sagittarius in the Polistinae, and Vespa affinis, $V$. analis and $V$. velutina (fig. 9) in the Vespinae.

Acknowledgsments: This research was funded by the Vietnam National Foundation for Science and Technology Development (NAFOSTED) under the grant number 106.122011.30 to the senior author.

\section{REFERENCES}

1. Carpeter J. M., 1991. Phylogenetic relationships and the origin of social behavior in the Vespidae. Pp 7-32 in K. R. Ross and R. W. Matthews (eds.), The Social Biology of Wasps. Cornell University Press, Ithaca.

2. Carpenter J. M., 1996. Phylogeny and biogeography of Polistes. Pp 18-57 in S. Turillazzi and M. J. West-Eberhard (eds.), 
Natural History and Evolution of PaperWasps. Oxford University Press.

3. Carpenter J. M., 1996. Distributional checklist of species of the genus Polistes (Hymenoptera: Vespidae; Polistinae, Polistini). American Museum Novitates, 3188: 1-39.

4. Carpenter J. M., Kojima J., 1997. Checklist of the species in the subfamily Vespinae (Insecta: Hymenoptera: Vespidae). Natural History Bulletin of Ibaraki University, 1: 51-92.

5. Carpenter J. M., Kojima J., 1997. Checklist of the species in the subfamily Stenogastrinae (Hymenoptera: Vespidae). Journal of the New York Entomological Society, 104: 21-36.

6. Carpenter J. M., Starr C. K., 2000. A new genus of hover wasps from Southeast Asia (Hymenoptera: Vespidae; Stenogastrinae). American Museum Novitatates, 3291: 1-12.

7. Carpenter J. M., Wenzel J. W., 1999. The relative abundance of swarm-founding social wasps in the Congo Basin (Insecta: Hymenoptera: Vespidae: Polistinae). Natural History Bulletin of Ibaraki University, 3: 9-14.

8. Das B. P. and Gupta V. K., 1989. The social wasps of India and the Adjacent Countries (Hymenoptera: Vespidae). Oriental Insects Monograph, 11: 176-189.

9. Gadagkar R., 1991. Belonogaster, Mischocyttarus, Parapolybia, and Independent-founding Ropalidia. Pp 149190 in K. R. Ross and R. W. Matthews (eds.), The Social Biology of Wasps. Cornell University Press, Ithaca.

10. Gould W. P., Jeanne R. L., 1984. Polistes wasps (Hymenoptera: Vespidae) as control agents for lepidopterous cabbage pest. Enviromental Entomology, 13(1): 150-156.

11. Goulet H., Huber J. T., 1993. Hymenoptera of the world: An identification guide to families. Research Branch Agriculture Canada Publication 1894/E. 668pp.

12. Gusenleitner J., 2008. Vespidae aus den
Tanimbar-Inseln (Indonesien) in der Sammlung des Oberösterreichischen Landesmuseums (Hymenoptera: Vespidae: Polistinae, Eumeninae). Linzer Biologische Beitrage, 40(1): 765-770.

13. Gusenleitner J., 2011. Eine Aufsammlung von Faltenwespenaus Laos im Biologiezentrum Linz (Hymenoptera: Vespidae: Vespinae, Stenogastrinae, Polistinae, Eumeninae). Linzer Biologische Beitrage, 43(2): 1351-1368.

14. Itô Y., 1984. Social biology of tropical and subtropical paper wasps with special reference to theories of the evolution of eusociality in the Hymenoptera. News Bulletin of Enomological Society. Queensland, 12(6): 91-97.

15. Iwata K., 1967. Report of the foundamental research on the biological control of insect pests in Thailand II. The report on the bionomics of Aculeate wasps - Bionomics of subsocial wasps of Stenogastrinae (Hymenoptera: Vespidae). Nature \& Life in S.E. Asia, Tokyo 5: 259-293.

16. Jeanne R. L., 1980. Evolution of social behavior in the Vespidae. Annual Review of Entomoogy, 25: 371-396.

17. Khuat Dang Long, Nguyen Thi Phuong Lien, Pham Thi Nhi, 2004. A survey of beneficial hymenopteran bees and wasps and their use of value in the buffer zone of Cuc Phuong National Park, North Vietnam. Sylvatrop, 14(1-2): 67-94.

18. Kojima J., 1993. Relative abundance of swarm-founding Ropalidia in the eusocial wasps (Hymenoptera: Vespidae) in tropical Australia. New Entomologist, 4: 4-7.

19. Kojima J., 1999. Male genitalia and antennae in an Old World paper wasp genus Ropalidia Guérin-Méneville, 1831 (Insecta: Hymenoptera; Vespidae, Polistinae). Natural History Bulletin of Ibaraki University, 3: 51-68.

20. Kojima J., Carpenter J. M., 1997. Catalog of species in the polistine tribe Ropalidiini (Insecta: Hymenoptera: Vespidae). American Museum Novitates, 3199: 1-96. 
21. Kojima J., Lambert K., Nguyen L. T. P., Saito F., 2007. Taxonomic notes on the paper wasps of the genus Ropalidia in the Indian subcontinent (Hymenoptera: Vespidae). Entomological Science, 10: 373393.

22. Le Ba Thao, 2002. Vietnam's Territory and Geography. The Gioi Publisher, 609pp.

23. Nguyen T. P. Lien, Carpenter J. M., 2002. Vespidae of Vietnam (Insecta: Hymenoptera) 1. Vespinae. Journal of the New York Entomological Society, 110: 199-211.

24. Nguyễn Thị Phương Liên, Khuất Đăng Long, 2003. Kết quả khảo sát các loài ong xã hội (Hymenoptera: Vespidae) ở Vườn quốc gia $\mathrm{Ba}$ Vì và Tam Đảo. Báo cáo khoa học hội nghị toàn quốc lần thứ hai, nghiên cứu cơ bản trong sinh học, nông nghiệp, $\mathrm{y}$ học: 658-661.

25. Nguyễn Thị Phương Liên, Khuất Đăng Long, 2004. Nghiên cứu họ ong xã hội Vespidae ở Việt Nam và bổ sung ba loài thuộc giống Eustenogaster van der Vecht, 1969 (Hymenoptera: Vespidae: Stenogastrinae) cho khu hệ của Việt Nam. Tạp chí Sinh học, 26(3A): 38-42.

26. Nguyễn Thị Phương Liên, Vũ Quang Côn, 2004. Các loài ong xã hội thuộc giống Parapolybia de Sausure, 1854 (Hymenoptera: Vespidae: Stenogastrinae) ở Việt Nam. Tạp chí Sinh học, 26(3A): 43-47.

27. Nguyễn Thị Phương Liên, Kojima J., Saito F., 2005. Kết quả khảo sát các loài ong xã hội (Hymenoptera: Vespidae) ở Vườn Quốc gia Xuân Sơn và Cát Bà. Báo cáo khoa học Hội nghị toàn quốc, Đại học Y Hà Nội: 218220.

28. Nguyễn Thị Phương Liên, Phạm Huy Phong, 2011. Nghiên cứu về các loài ong xã hội bắt mồi họ Vespidae ở một số khu bảo tồn ở các tỉnh Tây Bắc Việt Nam. Hội nghị côn trùng học toàn quốc lần thứ 7 , Hà Nội: 848-851.

29. Nguyễn Thị Phương Liên, Fuki S., Kojima J., Carpenter J. M., 2005. Danh lục các loài ong xã hội (Hymenoptera: Vespidae) của Việt Nam. Hội thảo quốc gia về Sinh thái và Tài nguyên sinh vật lần thứ nhất, Hà Nội : 129-137.

30. Nguyen T. P. Lien, Junichi Kojima, Fuki Saito, 2011. Polistes (Polistella) wasps (Hymenoptera: Vespidae: Polistinae) from mountainousareas of northern Vietnam, with description of five new species. Zootaxa, 3060: 1-30.

31. Nguyen T. P. Lien, Saito F., Kojima J., Carpenter J. M., 2006. Vespidae of Vietnam (Insecta: Hymenoptera) 2. Taxonomic notes on Vespinae. Zoological Science, 23: 95104.

32. Nguyen L. T. P., Saito F., Kojima J., Carpenter J. M., 2006. Vespidae (Hymenoptera) of Viet Nam 3. Synoptic key to Vietnamese species of the polistine genus Ropalidia, with notes on taxonomy and distribution. Entomological Science, 9: 93107.

33. Saito F., 2009. New species of hover wasps genus Eustenogaster (Insecta: Hymenoptera: Vespidae: Stenogastrinae) from Southeast Asia. Species Diversity, 14: 15-25.

34. Saito F., Kojima J., 2007. A taxonomic revision of the hover wasp genus Eustenogaster van der Vecht (Insecta: Hymenoptera; Vespidae, Stenogastrinae). Zootaxa, 1556: 1-30.

35. Saito F., Nguyen L. T. P., Carpenter J. M., Kojima J., 2006. A new Eustenogaster species (Hymenoptera: Vespidae; Stenogastrinae), the first hover wasp known to over winter on the nest. American Museum Novitates, 3534: 1-11. 


\title{
NGHIÊN CÚU VỀ CÁC LOÀI ONG BẮT MỒI \\ (HYMENOPTERA: VESPIDAE) Ở VIẸT NAM VÀ PHÂN BỐ CỦA CHÚNG
}

\author{
Nguyễn Thị Phương Liên ${ }^{1}$, Junichi Kojima ${ }^{2}$ \\ ${ }^{1}$ Viện Sinh thái và Tài nguyên sinh vật, Viện Hàn lâm KH \& CN Việt Nam \\ ${ }^{2}$ Trường đại học Ibaraki, Nhật Bản
}

\section{TÓM TÁT}

Bài báo là kết quả tổng kết nghiên cứu về các loài ong bắt mồi thuộc họ Ong vàng (Vespidae) ở Việt Nam và đưa ra kiểu phân bố của chúng. Tổng số có 76 loài thuộc 11 giống được ghi nhận ở Việt Nam, bao gồm 11 loài thuộc bốn giống của phân họ Stenogastrinae, 51 loài thuộc bốn giống của phân họ Polistinae và 14 loài thuộc ba giống của phân họ Vespidae. Ghi nhận về phân bố của tất cả các loài ong bắt mồi ở ba điều kiện khí hậu (phía Bắc, phía Nam và khu vực miền núi) của Việt Nam được đưa ra, cho thấy số lượng các loài có xu hướng giảm từ Bắc xuống Nam và khu vực miền núi là nơi có số lượng loài được ghi nhận nhiều nhất.

Khu hệ các loài ong bắt mồi của Việt Nam rất phong phú và bao gồm ba yếu tố chính. Thứ nhất là yếu tố phía Bắc mà trong đó trung tâm của sự phát sinh có thể là ở sườn đông của dãy Himalaya bao gồm phía Bắc của Việt Nam. Một lượng lớn các loài ong bắt mồi của Việt Nam chịu ảnh hưởng của yếu tố này. Yếu tố thứ hai có thể là yếu tố Sundaland, bao gồm những loài có phân bố ở phía Nam của Việt Nam. Yếu tố thứ ba gồm những loài có phân bố rộng khắp từ Ấn Độ đến Ôxtrâylia, và thậm chí ở cả khu vực Papuan. Việt Nam có khu hệ các loài ong bắt mồi phong phú không chỉ vì vị trí địa lý rất đặc thù của nó, mà còn vì các vùng của đất nước có các điều kiện khí hậu khác nhau, là nơi trú ẩn cho các loài ong thích nghi với các điều kiện môi trường sống khác nhau.

Tư khóa: Vespidae, điều kiện khí hậu, ong bắt mồi, khu hệ, phân bố, Việt Nam.

Ngày nhận bài: 9-1-2013 